\title{
Incidence and Prevention of Invasive Meningococcal Disease in Global Mass Gathering Events
}

\author{
Abdul Razak Muttalif · Jessica V. Presa - Hammam Haridy • \\ Amgad Gamil · Lidia C. Serra • Alejandro Cané
}

Received: June 6, 2019 / Published online: August 30, 2019

(C) The Author(s) 2019

\section{ABSTRACT}

Introduction: Mass gathering events involve close contact among large numbers of people in a specific location at the same time, an environment conducive to transmission of respiratory tract illnesses including invasive meningococcal disease (IMD). This report describes IMD incidence at mass gatherings over the past 10 years and discusses strategies to prevent IMD at such events.

Methods: A PubMed search was conducted in December 2018 using a search string intended to identify articles describing IMD at mass

Enhanced Digital Features To view enhanced digital features for this article go to https://doi.org/10.6084/ m9.figshare.9548588.

A. R. Muttalif

MAHSA University, 42610 Bandar Saujana Putra,

Selangor, Malaysia

J. V. Presa $(\varangle) \cdot$ L. C. Serra

Pfizer Vaccines, Pfizer Inc, 500 Arcola Road,

Collegeville, PA 19426, USA

e-mail: jessica.presa@pfizer.com

H. Haridy · A. Gamil

Pfizer Vaccines, Pfizer Inc, Pfizer Building 6, Dubai

Media City, Dubai, United Arab Emirates

\section{A. Cané}

Pfizer Biopharmaceuticals Group, Complejo Thames Office Park, Colectora Panamericana 1804, 1 Piso

Sector "B" Lado Sur, CP 1607EEV Villa Adelina, Pcia

Buenos Aires, Argentina gatherings, including religious pilgrimages, sports events, jamborees, and refugee camps. The search was limited to articles in English published from 2008 to 2018. Articles were included if they described IMD incidence at a mass gathering event.

Results: A total of 127 articles were retrieved, of which 7 reported on IMD incidence at mass gatherings in the past 10 years. Specifically, in Saudi Arabia between 2002 and 2011, IMD occurred in 16 Hajj pilgrims and 1 Umrah pilgrim; serotypes involved were not reported. At a youth sports festival in Spain in 2008, 1 case of serogroup B IMD was reported among 1500 attendees. At the 2015 World Scout Jamboree in Japan, an outbreak of serogroup W IMD was identified in five scouts and one parent. At a refugee camp in Turkey, one case of serogroup B IMD was reported in a Syrian girl; four cases of serogroup X IMD occurred in an Italian refugee camp among refugees from Africa and Bangladesh. In 2017, a funeral in Liberia resulted in 13 identified cases of serogroup C IMD. Requiring meningococcal vaccination for mass gathering attendees and vaccinating refugees might have prevented these IMD cases.

Conclusions: Mass gathering events increase IMD risk among attendees and their close contacts. Vaccines preventing IMD caused by serogroups ACWY and B are available and should be recommended for mass gathering attendees. Funding: Pfizer. 
Keywords: Invasive meningococcal disease; Mass gathering; Neisseria meningitidis; Vaccination

\section{INTRODUCTION}

Mass gatherings are defined by the World Health Organization and Centers for Disease Control and Prevention as concentrations of people at a specific location for a specific purpose, with the potential to strain local resources $[1,2]$. These events include planned activities such as large sporting events (e.g., Olympics, FIFA World Cup), business expositions, music festivals, funerals of religious or political figures, and religious pilgrimages (e.g., the Hindu pilgrimage of Kumbh Mela in India and the annual Hajj and Umrah pilgrimages in Saudi Arabia), as well as unplanned gatherings, such as refugee camps and protests [1]. Unfortunately, the inherent properties of these events (i.e., a single location where a large number of individuals congregate who often traveled internationally) increase the likelihood of transmission of communicable diseases [1]. Transmission of such diseases not only occurs between attendees but can also occur from the local population in the host country to the mass gathering attendees, from the attendees to the local population, or from attendees infected in the host country to people in their native country on return from the event [1]. Because of the potential for rapid acquisition and spread of disease during mass gathering events, preventive measures are crucial to maintain public health and safety.

Among numerous communicable diseases associated with mass gathering events, respiratory tract infections have been designated by the World Health Organization as a public health concern [1]. Within this group, invasive meningococcal disease (IMD) has been highlighted as a specific and critical public health issue, given the emergence of outbreaks linked to mass gathering events such as the Hajj and Umrah [3, 4].

Invasive meningococcal disease is caused by the bacterium Neisseria meningitidis [5]. Asymptomatic colonization of the mucosal surfaces of the nasopharynx by N. meningitidis is common, particularly among adolescents and young adults [6]. Transmission of N. meningitidis from asymptomatic carriers or people with IMD occurs through direct contact with large-droplet respiratory tract secretions [6]. Although most carriers of meningococci are asymptomatic, in a small percentage of cases $(<1 \%)$ bacteria cross the mucosa, enter the bloodstream, and cause IMD [5].

Invasive meningococcal disease causes substantial morbidity and mortality worldwide [7]. Typical IMD symptoms are fever, headache, and stiff neck as well as nausea, vomiting, photophobia, and altered mental state [5]. Onset of symptoms usually is rapid [8], and severe illness can ensue within 15-24 h after infection in infants and older children [9]; $10-15 \%$ of people with IMD die even with appropriate and timely treatment [5]. Among those who survive IMD, 3-21\% could experience serious clinical sequelae, including limb loss, hearing loss, chronic pain, skin scarring, and neurologic deficits [10].

The rapidity of IMD symptom onset and disease progression poses additional challenges in mass gathering settings. Specifically, infected individuals require timely access to medical professionals in conjunction with prompt and accurate diagnosis and effective treatment; early detection requires that good surveillance systems are in place before the event [1]. Mass gatherings, by definition, strain local healthcare resources [1, 2], which complicates patient management.

Awareness of the incidence of IMD occurring during mass gatherings, including unplanned gatherings such as refugee camps, can provide useful information for designing and implementing appropriate preventive strategies, including recommendations for vaccination. This is especially important for planned mass gathering events, such as the Hajj pilgrimage, in which host countries can undertake a risk assessment that includes the potential for transmission of diseases such as IMD [1]. Such anticipatory planning can help ensure that procedures are in place to quickly address any disease outbreaks [1]. A better understanding of disease incidence at recent events can aid in such planning. Therefore, this review summarizes the incidence of IMD reported at mass 
gathering events worldwide during the past decade and the role vaccination has in preventing outbreaks.

\section{LITERATURE SEARCH CRITERIA AND RESULTS}

A PubMed search was conducted in December 2018 using the search string: [Meningococcal OR (N. meningitidis) OR (Neisseria meningitidis) OR (meningitis)] AND each of the following terms: Hajj OR Umrah; Kumbh Mela; mass gather; Olympic; World Cup; refugee; funeral; concert; jamboree. Limits were human, English, and past 10 years. Articles were selected for inclusion if they described the incidence of IMD at a mass gathering event; articles that did not report data on IMD cases or did not include a mass gathering event were excluded; articles with "review" in the title also were excluded. A total of 127 articles were retrieved, of which 27 were considered for further review based on their abstract; after review of the full articles, 7 were identified as meeting the inclusion criteria and are summarized below per mass gathering event. This article is based on previously conducted studies and does not contain any studies with human participants or animals performed by any of the authors.

\section{INVASIVE MENINGOCOCCAL DISEASE DURING MASS GATHERING EVENTS FROM 2008-2018}

\section{Hajj and Umrah}

The Hajj is an annual 5-day pilgrimage to Makkah, Saudi Arabia, undertaken by all Muslims who are physically able and have the financial means to do so $[11,12]$. Although the Hajj lasts only 5 days, most pilgrims remain in Saudi Arabia for several weeks [3]. Umrah is similar to the Hajj in that it is a pilgrimage to Makkah, but travel can be completed at any time of year, and the length of the pilgrimage is shorter [11].

The Hajj pilgrimage is one of the world's largest annual religious mass gatherings, with about 2-3 million pilgrims from more than 184 countries participating each year [3, 11]. The Hajj brings together a geographically diverse population in close proximity, creating ideal conditions for transmission of communicable respiratory tract infections [11].

The spread of infectious diseases during the Hajj has been well documented and is attributable to crowded conditions, shared facilities, extreme heat and humidity, extended time that pilgrims spend at Hajj sites, exhaustion from performing physically demanding Hajj rites, and attendance by elderly pilgrims in poor health $[11,13,14]$. Respiratory tract infections due to viral or bacterial pathogens are commonly reported among Hajj pilgrims [15]. Meningococcal infections in particular have been associated with the Hajj, including a large outbreak in 1987 that affected pilgrims in Saudi Arabia before becoming a global outbreak when pilgrims completed the Hajj and returned home [16].

Within the 2008-2018 time frame set as an inclusion criterion for this review, one article was published that reported IMD incidence at the Hajj or Umrah between 1995 and 2011 (Table 1) [17]. During the time period of 2002-2011, IMD was confirmed in 16 Hajj pilgrims and 1 Umrah pilgrim. This is a considerable decrease from the number of cases reported during IMD outbreaks in 2000 and 2001, during which 223 Hajj pilgrims and 26 Umrah pilgrims contracted IMD. The incidence rate in 2002-2011 also was lower than that reported for the period from 1995 to 1999, when IMD occurred in 60 Hajj pilgrims and 46 Umrah pilgrims. These decreases likely reflect the diverse preventive measures instituted by the Kingdom of Saudi Arabia between 1988 and 2002, including a quadrivalent $\mathrm{A} / \mathrm{C} / \mathrm{W} / \mathrm{Y}$ meningococcal polysaccharide vaccine requirement for all Hajj and Umrah pilgrims and meningococcal vaccination programs targeting Hajj workers and residents of Mecca, Medina, and surrounding areas [18].

\section{Nasopharyngeal Carriage}

Between $8-25 \%$ of the general population are asymptomatic nasopharyngeal carriers of $N$. meningitidis [19]. Hajj pilgrims typically have 


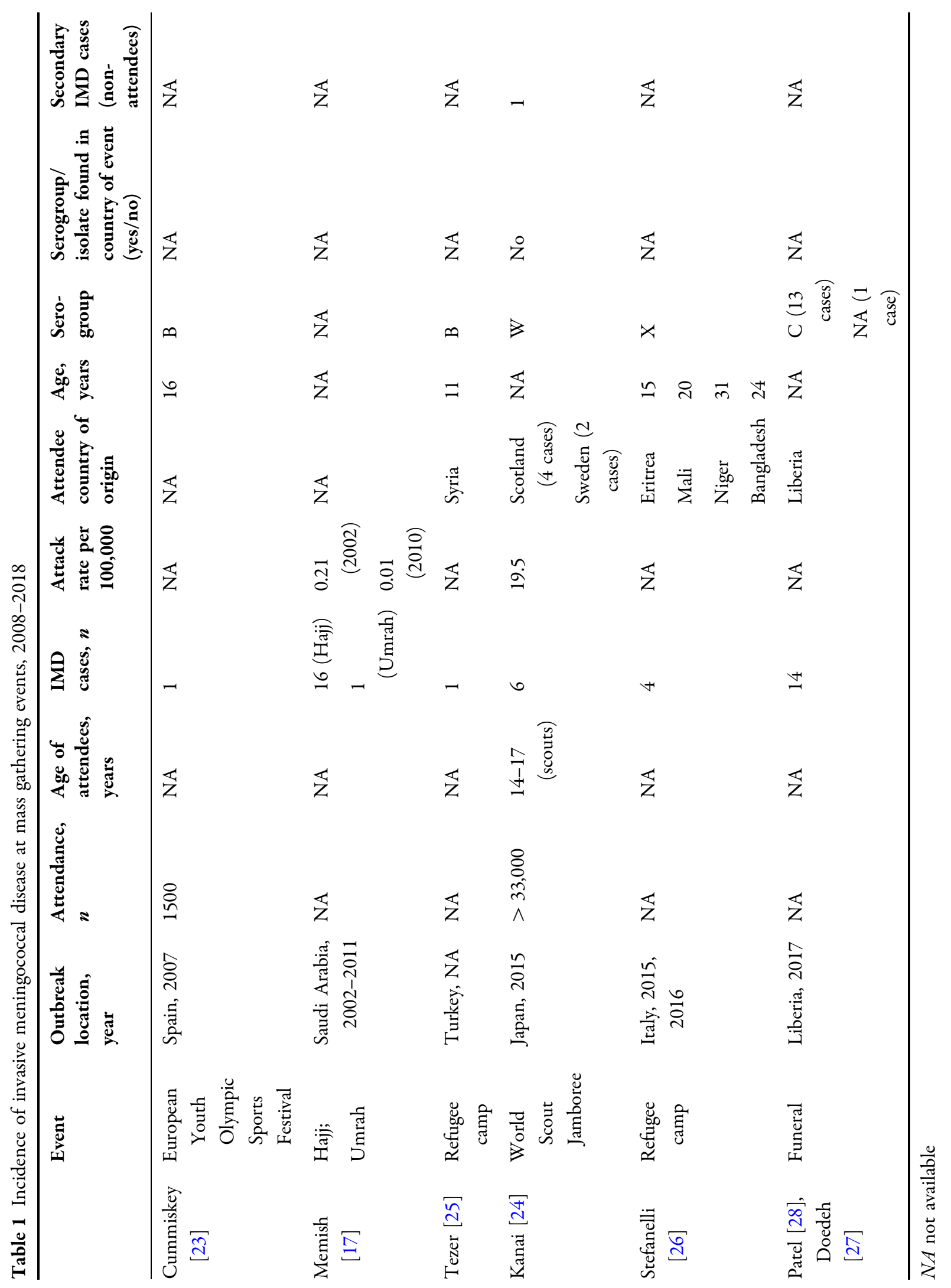


meningococcal nasopharyngeal carriage rates of $5-10 \%$ [20]. Studies of residents living near the Haram (Holy Mosque) in 1992 [21] and 2001 [22] reported overall meningococcal carriage rates of $86 \%$ and $7.4 \%$, respectively. Overcrowded conditions, humidity, and air pollution are implicated in these rates [15].

\section{Other Mass Gathering Events}

Cases of IMD at mass gathering events other than the Hajj and Umrah published within the 2008-2018 time frame were reported at one sports festival [23]; the World Scout Jamboree [24]; two refugee camps, one in Turkey [25] and the other in Italy [26]; and one funeral [27, 28] (Table 1).

\section{Sporting Events}

A European Youth Olympic Sports Festival was held in January 2008 in Spain and was attended by 1500 athletes from 43 countries [23]. At this event, a 16-year-old ice hockey player became unwell, complaining of a stiff neck and fever. While in Spain, he was diagnosed with meningitis caused by serogroup B and treated with antibiotics. The patient recovered fully, had no early sequelae resulting from IMD, and was transported back to his native country.

The World Scout Jamboree held in Japan in the summer of 2015 was attended by more than 33,000 scouts and leaders from 155 countries [24]. After the jamboree concluded, six cases of IMD were reported by public health agencies in the attendees' native countries [three scouts and one household contact (parent) from Scotland and two scouts from Sweden]. All patients recovered with treatment. All six cases were attributable to serogroup $\mathrm{W}$, an uncommon serogroup in Japan where the jamboree took place.

\section{Refugee Camps}

In Turkey, IMD caused by serogroup B was reported in an 11-year-old refugee girl from Syria [25]. The patient responded to a 10-day course of antibiotics. Whether the serogroup $B$ strain was acquired in Turkey or Syria could not be determined because the patient had resided in Turkey for only 3 months at the time IMD developed.

In refugee camps in Italy, four cases of IMD caused by serogroup $X$ were reported, one in 2015 and three in 2016 [26]. The affected patients were a 15-year-old female from Eritrea, a 20-year-old male from Mali, a 31-year-old male from Niger, and a 24-year-old male from Bangladesh. Three of the affected patients developed symptoms shortly after arriving in Italy; the remaining patient (a Bangladeshi male) was in a camp with other African refugees for several months before disease onset. All four patients recovered with antibiotic treatment.

\section{Funerals}

Across 3 counties in Liberia, 31 cases of unexplained illness and death were reported among individuals that attended a 2-day funeral in 2017 [27, 28]. The onset of unexplained illnesses was tightly clustered over 10 days and included 13 deaths. Subsequent laboratory testing of 24 patients detected N. meningitidis in 14 patients, with serogroup C linked to 13 patients. Further, N. meningitidis was identified in $100 \%(11 / 11)$ of the fatal cases with available specimens. Reports from one of the three affected counties show that patients recovered with supportive treatment including antibiotics.

\section{Kumbh Mela}

No specific cases of IMD were identified for Kumbh Mela, a large pilgrimage that occurs once every 3 years to one of four river banks in India [29]. However, several serogroup A meningococcal outbreaks affecting mainly the northern cities of India have been reported. Although not confirmed, overcrowding during the Kumbh Mela has the potential to result in meningococcal transmission. Other infections such as influenza, measles, chicken pox, pertussis, and mumps also have the potential to spread during the Kumbh Mela [29]. 
Table 2 Available meningococcal vaccines

\begin{tabular}{|c|c|c|c|c|}
\hline Serogroup & $\begin{array}{l}\text { Vaccine } \\
\text { formulation }\end{array}$ & Vaccine type & Vaccine name & Manufacturer \\
\hline A & MenA-TT & Conjugate & $\begin{array}{l}\text { MenAfriVac } \\
\quad[58]\end{array}$ & $\begin{array}{l}\text { Serum Institute of } \\
\text { India }\end{array}$ \\
\hline \multirow[t]{2}{*}{ B } & MenB-FHbp & Recombinant (FHbp subfamily A and B) & $\begin{array}{l}\text { Trumenba } \\
\text { [59] }\end{array}$ & Pfizer \\
\hline & MenB-4C & $\begin{array}{l}\text { Recombinant (FHbp subfamily B, NadA, } \\
\text { NHBA, OMV) }\end{array}$ & $\begin{array}{l}\text { Bexsero } \\
{[45,60]}\end{array}$ & GlaxoSmithKline \\
\hline \multirow[t]{4}{*}{$\mathrm{C}$} & MCC-TT & Conjugate & $\begin{array}{l}\text { NeisVac-C } \\
\quad[61]\end{array}$ & Pfizer \\
\hline & Hib-MCC-TT & Conjugate & $\begin{array}{l}\text { Menitorix } \\
{[62]}\end{array}$ & GlaxoSmithKline \\
\hline & MCC-CRM & Conjugate & $\begin{array}{l}\text { Menjugate } \\
\quad[63]\end{array}$ & Novartis \\
\hline & MCC-CRM & Conjugate & $\begin{array}{l}\text { Meningitec } \\
\quad[64]\end{array}$ & Pfizer \\
\hline $\mathrm{C}+\mathrm{Y}$ & Hib-MenCY-TT & Conjugate & $\begin{array}{l}\text { MenHibrix } \\
\quad[65]\end{array}$ & GlaxoSmithKline \\
\hline \multirow[t]{3}{*}{ ACWY } & MenACWY-DT & Conjugate & Menactra [41] & Sanofi Pasteur \\
\hline & $\begin{array}{l}\text { MenACWY- } \\
\text { CRM }\end{array}$ & Conjugate & Menveo $[66]$ & GlaxoSmithKline \\
\hline & MenACWY-TT & Conjugate & Nimenrix [67] & Pfizer \\
\hline
\end{tabular}

$C R M$ cross-reactive material, DT diphtheria toxoid, FHbp factor $\mathrm{H}$ binding protein, Hib Haemophilus influenzae type $\mathrm{B}$, $M C C$ meningococcal serogroup $\mathrm{C}$ conjugate, $N a d A$ neisserial adhesin A, NHBA neisserial heparin-binding antigen, $O M V$ outer membrane vesicles, $T T$ tetanus toxoid

\section{VACCINATION AS A TOOL TO PREVENT INVASIVE MENINGOCOCCAL DISEASE AT MASS GATHERINGS}

\section{Vaccines Available}

Vaccination is an effective strategy of reducing the incidence of meningococcal disease because of serogroups included in the vaccine formulation [30]. N. meningitidis is categorized into 12 serogroups according to the biochemical composition of the capsular polysaccharide; however, only 6 serogroups (A, B, C, W, X, and Y) are responsible for most meningococcal disease
[7], and vaccines are available for 5 of these serogroups [6, 31]. No vaccine is currently available against disease caused by serogroup X, although multivalent vaccines that cover serogroup $X$ are in development $[32,33]$. Moreover, studies suggest that serogroup B vaccines may provide some protection against serogroup $\mathrm{X}$ disease $[34,35]$, as described below.

Polysaccharide-based vaccines in bivalent and quadrivalent forms that target serogroups A, C, W, and/or Y have successfully protected mass gathering attendees [20]. However, there are major limitations to polysaccharide vaccines, including insufficient protection for toddlers and children as well as an inability to provide long-lasting or substantial herd 
immunity [36, 37]. More recently, polysaccharide-based conjugate vaccines with improved immunogenicity $[38,39]$ targeting serogroups $\mathrm{A}, \mathrm{C}, \mathrm{W}$, and $\mathrm{Y}$ have been used in both monovalent and polyvalent forms to successfully prevent disease due to these serogroups; monovalent vaccines for serogroups $\mathrm{A}$ and $\mathrm{C}$ are not commonly used for vaccination of mass gathering attendees. Three quadrivalent vaccines are available for prevention of IMD caused by serogroups A, C, W, and Y [39, 40]: MenACWY-DT (Menactra $^{\circledR}$, conjugated to diphtheria toxin; Sanofi Pasteur Inc., Swiftwater, PA, USA) [41]; MenACWY-CRM (Menveo ${ }^{\circledR}$, conjugated to C-reactive protein; Novartis Vaccines and Diagnostics Srl, Sovicille, Italy) [42]; and MenACWY-TT $\left(\right.$ Nimenrix $^{\circledR}$, conjugated to tetanus toxoid; Pfizer Ltd, Sandwich, UK) [43] (Table 2).

Two recombinant protein-based vaccines specifically targeting serogroup $\mathrm{B}$ also are available: MenB-FHbp (Trumenba ${ }^{\circledR}$, bivalent rLP2086; Pfizer Inc, Philadelphia, PA, USA) [44] and MenB-4C (Bexsero ${ }^{\circledR}$, 4CMenB; GlaxoSmithKline Vaccines, Srl, Siena, Italy) [45] (Table 2). Notably, both serogroup B vaccines contain one or both variants of the factor $\mathrm{H}$ binding protein (FHbp) [46], a meningococcal outer membrane protein found in most IMD strains $[47,48]$. Therefore, these vaccines could potentially provide protection against additional meningococcal serogroups [48]. Recent work has highlighted that MenB-4C elicited immune responses against serogroup $X$ strains [34], while MenB-FHbp demonstrated immune responses greater than the serologic correlate of protection against serogroup $\mathrm{C}, \mathrm{W}, \mathrm{Y}$, and $\mathrm{X}$ strains [49]. However, these results are preliminary, and additional clinical studies are required to fully evaluate the potential applicability of serogroup B vaccines in broad IMD protection.

\section{Vaccination Strategies Previously Used at Mass Gathering Events}

The incidence of IMD due to serogroups A, B, C, $\mathrm{W}, \mathrm{X}$, and $\mathrm{Y}$ varies globally; therefore, awareness of the local epidemiology at the site of the mass gathering is important. However, the nature of mass gathering events, which involves attendees traveling to the host country, can introduce new isolates or serogroups that change the local epidemiology.

Vaccination before attendance at a mass gathering event, such as Hajj, Umrah, Kumbh Mela, and sport gatherings, can lower the risk of IMD. The benefits of vaccination and its effect on IMD incidence at a mass gathering were exemplified by the response of Saudi Arabia after the 1987 Hajj meningococcal serogroup A outbreak. Beginning in 1988, Saudi Arabia required mandatory serogroup $\mathrm{A}$ and $\mathrm{C}$ vaccination for all pilgrims and all other Hajj attendees and workers [18]. Free vaccination was also offered to residents living in neighboring areas [18]. In 1997, in response to an increase in cases of serogroup A disease, vaccination was coupled with antibiotic prophylaxis of Hajj pilgrims traveling from areas with endemic disease, which decreased IMD incidence until 1999 [18]. In 1987, the year of the meningococcal serogroup A outbreak, the incidence rate of IMD in Saudi Arabia was 12.83 cases per 100,000 people [20]. Between 1995 and 1999, the mean annual incidence was 0.20 cases per 100,000 (range 0.25 cases per 100,000 in 1995 to 0.06 cases per 100,000 in 1999) [20].

Mandatory vaccination of Hajj pilgrims against serogroup A in the late 1990s saw the emergence of IMD caused by serogroup W-135. In 2000, an IMD outbreak caused by serogroup W occurred among Hajj pilgrims and their close contacts, ultimately spreading globally and to people with no connection with the Hajj attendees; 90 cases were reported in 9 countries between March and July of that year [50]. In May 2001, a quadrivalent meningococcal vaccine against serogroups $\mathrm{A}, \mathrm{C}, \mathrm{Y}$, and $\mathrm{W}$ became a requirement for all Hajj pilgrims [50].

\section{Considerations for Optimizing Vaccination Strategies for Mass Gatherings}

Preventing IMD among mass gathering attendees requires a high rate of vaccine uptake, particularly among those at highest risk for transmission, such as travelers from areas with endemic disease and those with a high rate of 
carriage (e.g., adolescents). Importantly, however, vaccination during a mass gathering event may not be efficacious because of the 7- to 10-day lag in development of protective antibodies [51]. Therefore, attendees must be vaccinated before rather than during the event. Moreover, vaccination efforts need to target not only those attending the mass gathering event but also event staff, healthcare workers, and residents of areas near the event location.

Compliance with meningococcal vaccination before traveling to Hajj is a key aspect of prevention. A survey conducted in Saudi Arabia in 2009 revealed that only $75 \%$ received meningococcal vaccination before traveling to Hajj [52]. Meningococcal vaccination compliance may be less for pilgrims traveling for Umrah, despite mandatory recommendations.

Vaccine recommendations for mass gathering attendees must also account for changes in local epidemiology. Although the availability of quadrivalent vaccines allows for broader coverage compared with monovalent and bivalent formulations, these vaccines do not cover serogroup B disease. Therefore, it is important to continually monitor local serogroup B epidemiology and update recommendations for vaccination with a recombinant serogroup $B$ vaccine as needed.

As of December 2018, travelers aged $\geq 2$ years to Saudi Arabia who are Hajj or Umrah pilgrims, seasonal workers, or workers in contact with pilgrims are required to show proof of vaccination with a polysaccharide or conjugate quadrivalent ACWY vaccine administered at least 10 days and not more than 3 years (polysaccharide vaccine) or 5 years (conjugate vaccine) before arrival in the country [53]. Travelers from countries in the meningitis belt of Africa are vaccinated on arrival in Saudi Arabia [53]. Vaccination with a serogroup B vaccine is not currently required for entry to Saudi Arabia.

In Japan and Spain, which had IMD outbreaks at mass gathering events, and in Italy and Turkey, countries hosting refugees from the Middle East and Africa in whom IMD has occurred, meningococcal vaccine is recommended depending on the traveler's age, health, lifestyle, and occupational risk, but it is not required for entry [54-57].

\section{CONCLUSIONS}

Mass gathering events predispose attendees of the event and the local population to communicable diseases, including IMD. Within the past decade, IMD has been reported at the annual Hajj and Umrah pilgrimages [17], the World Scout Jamboree in Japan [24], and a European youth sports festival in Spain [23], in refugee camps in Turkey [25] and Italy [26], as well as a funeral in Liberia $[27,28]$. Vaccination is the best option for preventing IMD at mass gathering events. Communicating the need for meningococcal vaccination to mass gathering attendees through print and online communications or by travel agents is key to increasing the number of vaccinated travelers.

\section{ACKNOWLEDGEMENTS}

Funding. Sponsorship for this work and the Rapid Service Fees was funded by Pfizer. All authors had full access to the articles reviewed in this manuscript and take complete responsibility for the integrity and accuracy of this manuscript.

Medical Writing, Editorial, and Other Assistance. Editorial assistance in the preparation of this article was provided by Karen L. Zimmermann of Complete Healthcare Communications, LLC (North Wales, PA), a CHC Group company, and was funded by Pfizer Inc.

Authorship. All named authors meet the International Committee of Medical Journal Editors (ICMJE) criteria for authorship for this article, take responsibility for the integrity of the work as a whole, and have given their approval for this version to be published.

Disclosures. Dr Abdul Razak Muttalif has nothing to declare. Dr Jessica V. Presa is an employee of Pfizer. Dr Hammam Haridy is an employee of Pfizer. Dr Amgad Gamil is an employee of Pfizer. Dr Lidia C. Serra is an employee of Pfizer. Dr Alejandro Cané is an employee of Pfizer. 
Compliance with Ethics Guidelines. This article is based on previously conducted studies and does not contain any studies with human participants or animals performed by any of the authors.

Open Access. This article is distributed under the terms of the Creative Commons Attribution-NonCommercial 4.0 International License (http://creativecommons.org/licenses/ by-nc/4.0/), which permits any noncommercial use, distribution, and reproduction in any medium, provided you give appropriate credit to the original author(s) and the source, provide a link to the Creative Commons license, and indicate if changes were made.

\section{REFERENCES}

1. World Health Organization. Public health for mass gatherings: key considerations. Available at: http:// apps.who.int/iris/bitstream/handle/10665/162109/ WHO_HSE_GCR_2015.5_eng.pdf. Accessed December $4,2018$.

2. Centers for Disease Control and Prevention. Travel to mass gatherings. Available at: https://wwwnc. cdc.gov/travel/yellowbook/2018/advising-travelerswith-specific-needs/travel-to-mass-gatherings. Accessed December 10, 2018.

3. Parker S. The Hajj: a constant travel destination amidst changing times. South Afr J Epidemiol Infect. 2010;25:14-8.

4. Badahdah AM, Rashid H, Khatami A, Booy R. Meningococcal disease burden and transmission in crowded settings and mass gatherings other than Hajj/Umrah: a systematic review. Vaccine. 2018;36:4593-602.

5. Hamborsky J, Kroger A, Wolfe S. Epidemiology and Prevention of Vaccine-Preventable Diseases, 13th ed. Washington: Public Health Foundation; 2015.

6. Cohn AC, MacNeil JR, Clark TA, et al. Prevention and control of meningococcal disease: recommendations of the Advisory Committee on Immunization Practices (ACIP). MMWR Recomm Rep. 2013;62:1-28.

7. Jafri RZ, Ali A, Messonnier NE, et al. Global epidemiology of invasive meningococcal disease. Popul Health Metr. 2013;11:11-7.
8. Crum-Cianflone N, Sullivan E. Meningococcal vaccinations. Infect Dis Ther. 2016;5:89-112.

9. Thompson MJ, Ninis N, Perera R, et al. Clinical recognition of meningococcal disease in children and adolescents. Lancet. 2006;367:397-403.

10. Pace D, Pollard AJ. Meningococcal disease: clinical presentation and sequelae. Vaccine. 2012;30:B3-9.

11. Memish ZA, Zumla A, Alhakeem RF, et al. Hajj: infectious disease surveillance and control. Lancet. 2014;383:2073-82.

12. Gatrad AR, Sheikh A. Hajj: journey of a lifetime. BMJ. 2005;330:133-7.

13. Ahmed QA, Arabi YM, Memish ZA. Health risks at the Hajj. Lancet. 2006;367:1008-15.

14. Shibl A, Tufenkeji $H$, Khalil $M$, Memish $Z$, Meningococcal Leadership Forum Expert Group. Consensus recommendation for meningococcal disease prevention for Hajj and Umra pilgrimage/travel medicine. East Mediterr Health J. 2013;19:389-92.

15. Memish ZA. The Hajj: communicable and noncommunicable health hazards and current guidance for pilgrims. Euro Surveill. 2010;15:19671.

16. Moore PS, Reeves MW, Schwartz B, Gellin BG, Broome CV. Intercontinental spread of an epidemic group A Neisseria meningitidis strain. Lancet. 1989;2:260-3.

17. Memish Z, Al Hakeem R, Al Neel O, et al. Laboratory-confirmed invasive meningococcal disease: effect of the Haji vaccination policy, Saudi Arabia, 1995-2011. Euro Surveill. 2013;18:20581.

18. Yezli S, Bin Saeed AA, Assiri AM, et al. Prevention of meningococcal disease during the Hajj and Umrah mass gatherings: past and current measures and future prospects. Int J Infect Dis. 2016;47:71-8.

19. Rouphael NG, Stephens DS. Neisseria meningitidis: biology, microbiology, and epidemiology. Methods Mol Biol. 2012;799:1-20.

20. Yezli S, Assiri AM, Alhakeem RF, Turkistani AM, Alotaibi B. Meningococcal disease during the Hajj and Umrah mass gatherings. Int $\mathrm{J}$ Infect Dis. 2016;47:60-4.

21. al-Gahtani YM, el-Bushra HE, al-Qarawi SM, alZubaidi AA, Fontaine RE. Epidemiological investigation of an outbreak of meningococcal meningitis in Makkah (Mecca), Saudi Arabia, 1992. Epidemiol Infect. 1995;115:399-409. 
22. Balkhy HH, Memish ZA, Osoba AO. Meningococcal carriage among local inhabitants during the pilgrimage 2000-2001. Int J Antimicrob Agents. 2003;21:107-11.

23. Cummiskey J, Borrione P, Bachil N, Ergen E, Pigozzi F. Report of a serious reportable communicable disease at a major sporting event. J Sports Med Phys Fitness. 2008;48:125-8.

24. Kanai M, Kamiya H, Smith-Palmer A, et al. Meningococcal disease outbreak related to the World Scout Jamboree in Japan, 2015. West Pac Surveill Response J. 2017;8:25-30.

25. Tezer H, Ozkaya-Parlakay A, Kanik-Yuksek S, Gulhan B, Guldemir D. A Syrian patient diagnosed with meningococcal meningitis serogroup B. Hum Vaccin Immunother. 2014;10:2482.

26. Stefanelli $\mathrm{P}$, Neri A, Vacca $\mathrm{P}$, et al. Meningococci of serogroup X clonal complex 181 in refugee camps, Italy. Emerg Infect Dis. 2017;23:870-2.

27. Doedeh J, Frimpong JA, Yealue KDM 2nd, et al. Rapid field response to a cluster of illnesses and deaths-Sinoe County, Liberia, April-May, 2017. MMWR Morb Mortal Wkly Rep. 2017;66:1140-3.

28. Patel JC, George J, Vuong J, et al. Rapid laboratory identification of Neisseria meningitidis serogroup C as the cause of an outbreak-Liberia, 2017. MMWR Morb Mortal Wkly Rep. 2017;66:1144-7.

29. Sridhar S, Gautret P, Brouqui P. A comprehensive review of the Kumbh Mela: identifying risks for spread of infectious diseases. Clin Microbiol Infect. 2015;21:128-33.

30. Prasad K, Karlupia N. Prevention of bacterial meningitis: an overview of Cochrane systematic reviews. Respir Med. 2007;101:2037-43.

31. Balmer P, York LJ. Optimal use of meningococcal serogroup B vaccines: moving beyond outbreak control. Ther Adv Vaccines Immunother. 2018;6:49-60.

32. Delrieu I, Yaro S, Tamekloe TA, et al. Emergence of epidemic Neisseria meningitidis serogroup X meningitis in Togo and Burkina Faso. PLoS One. 2011;6:e19513.

33. Chen WH, Neuzil KM, Boyce CR, et al. Safety and immunogenicity of a pentavalent meningococcal conjugate vaccine containing serogroups $\mathrm{A}, \mathrm{C}, \mathrm{Y}$, $\mathrm{W}$, and $\mathrm{X}$ in healthy adults: a phase 1 , single-centre, double-blind, randomised, controlled study. Lancet Infect Dis. 2018;18:1088-96.

34. Hong E, Giuliani MM, Deghmane AE, et al. Could the multicomponent meningococcal serogroup B vaccine (4CMenB) control Neisseria meningitidis capsular group $\mathrm{X}$ outbreaks in Africa? Vaccine. 2013;31:1113-6.

35. Harris S, Tan C, Andrew L, et al. Trumenba ${ }^{\circledR}$ elicits bactericidal antibodies against non-serogroup B meningococci. Presented at: European Society for Paediatric Infectious Diseases, May 23-27, 2017; Madrid, Spain.

36. Harrison LH. Prospects for vaccine prevention of meningococcal infection. Clin Microbiol Rev. 2006;19:142-64.

37. Chang Q, Tzeng YL, Stephens DS. Meningococcal disease: changes in epidemiology and prevention. Clin Epidemiol. 2012;4:237-45.

38. Dretler AW, Rouphael NG, Stephens DS. Progress toward the global control of Neisseria meningitidis: 21st century vaccines, current guidelines, and challenges for future vaccine development. Hum Vaccin Immunother. 2018;14:1146-60.

39. Ali A, Jafri RZ, Messonnier N, et al. Global practices of meningococcal vaccine use and impact on invasive disease. Pathog Glob Health. 2014;108:11-20.

40. Hedari CP, Khinkarly RW, Dbaibo GS. Meningococcal serogroups A, C, W-135, and Y tetanus toxoid conjugate vaccine: a new conjugate vaccine against invasive meningococcal disease. Infect Drug Resist. 2014;7:85-99.

41. Menactra ${ }^{\circledR}$ (MCV4). Full prescribing information. Rockville: Sanofi Pasteur, 2011.

42. Menveo ${ }^{\circledR}$ (meningococcal [groups A, C, Y and W-135] oligosaccharide diphtheria $\mathrm{CRM}_{197}$ conjugate vaccine). Summary of Product Characteristics, GSK Vaccines, Srl, Via Fiorentia, Italy, 2017.

43. Nimenrix ${ }^{\circledR}$, Product Monograph. Kirkland: Pfizer Canada Inc; 2016.

44. Trumenba ${ }^{\circledR}$ (meningococcal group B vaccine). Full Prescribing Information. Philadelphia: Wyeth Pharmaceuticals Inc., a subsidiary of Pfizer Inc, 2016.

45. Bexsero ${ }^{\circledR}$ (meningococcal group B vaccine). Full Prescribing Information. Cambridge: Novartis, 2016.

46. Folaranmi T, Rubin L, Martin SW, et al. Use of serogroup B meningococcal vaccines in persons aged $\geq 10$ years at increased risk for serogroup $B$ meningococcal disease: recommendations of the Advisory Committee on Immunization Practices, 2015. MMWR Morb Mortal Wkly Rep. 2015;64:608-12. 
47. Beernink PT, Caugant DA, Welsch JA, Koeberling O, Granoff DM. Meningococcal factor H-binding protein variants expressed by epidemic capsular group A, W-135, and X strains from Africa. J Infect Dis. 2009;199:1360-8.

48. Harris SL, Zhu D, Murphy E, et al. Preclinical evidence for the potential of a bivalent fHBP vaccine to prevent Neisseria meningitidis serogroup C disease. Human Vaccines. 2011;7:68-74.

49. Harris SL, Tan C, Andrew L, et al. The bivalent factor $\mathrm{H}$ binding protein meningococcal serogroup $B$ vaccine elicits bactericidal antibodies against representative non-serogroup B meningococci. Vaccine. 2018;36:6867-74.

50. Aguilera JF, Perrocheau A, Meffre C, Hahne S, W135 Working Group. Outbreak of serogroup W135 meningococcal disease after the Hajj pilgrimage, Europe, 2000. Emerg Infect Dis. 2002;8:761-7.

51. MacNeil JR, Meyer SA. Chapter 3 Infectious Diseases Related to Travel: Meningococcal Disease. In: Centers for Disease Control and Prevention, Brunette GW, editors. CDC Yellow Book 2018: health information for international travel. New York: Oxford University Press; 2017.

52. Memish ZA, Assiri AM, Hussain R, Alomar I, Stephens G. Detection of respiratory viruses among pilgrims in Saudi Arabia during the time of a declared influenza $\mathrm{A}(\mathrm{H} 1 \mathrm{~N} 1)$ pandemic. J Travel Med. 2012;19:15-21.

53. International Association for Medical Assistance to Travellers. Saudia Arabia required vaccinations: meningococcal meningitis. Available at: https:// www.iamat.org/country/saudi-arabia/risk/ meningococcal-meningitis. Accessed December 12, 2018.

54. International Association for Medical Assistance to Travellers. Italy recommended vaccinations: routine immunizations. Available at: https://www. iamat.org/country/italy/risk/routine-

immunizations. Accessed December 12, 2018.

55. International Association for Medical Assistance to Travellers. Turkey recommended vaccinations: routine immunizations. Available at: https://www. iamat.org/country/turkey/risk/routineimmunizations. Accessed December 12, 2018.
56. International Association for Medical Assistance to Travellers. Spain recommended vaccinations: routine immunizations. Available at: https://www. iamat.org/country/spain/risk/routineimmunizations. Accessed January 7, 2019.

57. International Association for Medical Assistance to Travellers. Japan recommended vaccinations: routine immunizations. Available at: https://www. iamat.org/country/japan/risk/routineimmunizations. Accessed January 7, 2019.

58. MenAfriVac ${ }^{\circledR}$ (Meningococcal A conjugate vaccine lyophilized [PsA-TT]). Full Prescribing Information. Hadapsar: Serum Institute of India Pvt. Ltd. 2015.

59. Trumenba (MenB-FHbp). Full Prescribing Information. Philadelphia: Pfizer Inc, 2018.

60. Donald RG, Hawkins JC, Hao L, et al. Meningococcal serogroup $B$ vaccines: estimating breadth of coverage. Hum Vaccin Immunother. 2017;13:255-65.

61. NeisVac-C $C^{\circledR}$ Vaccine. Product Monograph. Kirkland: Pfizer Canada Inc, 2015.

62. Menitorix ${ }^{\circledR}$ (meningococcal polysaccharide conjugate vaccine [Hib-MenC]). Full Prescribing Information. Victoria: GlaxoSmithKline, 2016.

63. Menjugate ${ }^{\circledR}$ Product Monograph. Siena: Novartis Vaccines and Diagnostics; 2013.

64. Meningitec ${ }^{\circledR} 0.5 \mathrm{~mL}$. Product Information. West Ryde, New South Wales, Australia: Pfizer Australia Pty Ltd; 2011.

65. MENHIBRIX ${ }^{\circledR}$ (Hib-MenCY-TT). Full Prescribing Information. Rixensart: GlaxoSmithKline, 2013.

66. Menveo ${ }^{\circledR}$ (meningococcal [groups A, C, Y and W-135] oligosaccharide diphtheria $\mathrm{CRM}_{197}$ conjugate vaccine). Full Prescribing Information. Sovicille: Novartis, 2013.

67. Nimenrix (meningococcal group A, C, W-135 and Y conjugate vaccine). Summary of Product Characteristics. Sandwich: Pfizer Limited, 2017. 